Sybilla Daković

Uniwersytet Wrocławski

sybilla.dakovic@uwr.edu.pl

(iD https://orcid.org/0000-0003-1247-4660

\title{
Chorwacki przyimek protiv i jego polskie ekwiwalenty tłumaczeniowe
}

Streszczenie: Chorwacki przyimek protiv jest rzadkim przyimkiem o rekcji dopełniaczowej. Pomimo że źródła leksykograficzne odnotowują znaczenia przestrzenne i nieprzestrzenne tego przyimka, badania empiryczne potwierdzają tylko znaczenia $\mathrm{z}$ abstrakcyjnej domeny adwersatywności, tj. wyrażanie przeciwnego stanowiska, sprzeczność, brak zgody na coś, ograniczanie, przeciwdziałanie lub ochronę przed czymś.

Zadaniem, jakie stawiamy sobie w tym opacowaniu, jest ustalenie zasobu polskich ekwiwalentów przekładowych chorwackiego przyimka protiv. Analiza przeprowadzona jest na korpusie zdań ekscerpowanych ze współczesnej literatury chorwackiej i ich polskich przekładów. W artykule wykorzystana jest metoda ekwiwalencji przekładowej, wpisująca się w nurt językoznawstwa porównawczego.

Badanie składa się z dwóch części. W pierwszej ustalone są znaczenia przyimka protiv obecne w zgromadzonym korpusie oraz zbadane jest prawo i lewostronne otoczenie tego przyimka. Część drugą poświęcono ekwiwalencji. Przedstawiony jest zasób polskich odpowiedników i określone są ich cechy leksykalne, gramatyczne i semantyczne. Wskazane są podobieństwa i różnice w wyrażaniu podobnych treści w obu językach oraz podjęta jest próba ustalenia czynników wyboru przez thumacza poszczególnych ekwiwalentów, np. pod postacią ograniczenia w otoczeniu prawo- i lewostronnym, odcienia znaczeniowego czy wartości stylistycznej. Ważnym elementem badania jest analiza statystyczna, która obok charakterystyki semantycznej pomoże ustalić główny polski ekwiwalent chorwackiego przyimka protiv.

Przeprowadzone badanie może mieć wykorzystanie w praktyce leksykograficznej, w dydaktyce oraz w przekładzie.

Słowa kluczowe: przyimki, przypadki, ekwiwalencja przekładowa, język chorwacki, język polski 


\section{Wstęp}

Zadaniem, jakie stawiamy sobie w tym opracowaniu, jest ustalenie zasobu polskich ekwiwalentów przekładowych chorwackiego przyimka protiv oraz próba zbadania ich konkurencyjności. Użyta zostanie metoda konfrontacji przekładowej polegająca na inwentaryzacji odpowiedniości przekładowych $\mathrm{w}$ dwóch kodach $\mathrm{z}$ wykorzystaniem równoległego korpusu tekstów języka źródłowego, w tym przypadku chorwackiego oraz języka, na który te teksty zostały przetłumaczone, tj. polskiego. Ekwiwalencja ustanawiana jest na poziomie sytuacji komunikacyjnej (plan parole), relacja przekładowa zaś, to jest warstwa semantyczna, stanowi tertium comparationis ${ }^{1}$.

\section{Chorwacki przyimek protiv w świetle dotychczasowych badań}

Chorwacki przyimek protiv jest dość rzadkim przyimkiem wtórnym $^{2}$ o pochodzeniu prasłowiańskim i praindoeuropejskim, pojawiającym się we wszystkich stylach funkcjonalnych ${ }^{3}$. Przyimek ten ma dwa archaiczne warianty formalne: proti i protivu, występujące tylko w tekstach literackich ${ }^{4}$. Źródła leksykograficzne określają rekcję przyimka protiv jako dopełniaczową, jednak w użyciach archaicznych i w starych dziełach literackich można spotkać także rekcję celownikową5.

\footnotetext{
1 Vladmir Ivir, Teorija i tehnika prevođenja (Sremski Karlovci: Centar „Karlovačka gimnazija“, 1978), 89, 143.

2 Jego frekwencja wynosi 0,0307 i sytuuje się on na 28 miejscu w grupie przyimków zarejestrowanych przez Hrvatski čestotni rječnik (Milan Moguš, Maja Bratanić i Marko Tadić, Hrvatski čestotni rječnik (Zagreb: Školska knjiga, 1999)).

${ }^{3}$ Moguš, Bratanić i Tadić, Hrvatski čestotni rječnik, 484.

${ }^{4}$ Frekwencja, jaką podaje Hrvatski čestotni rječnik (Moguš, Bratanić i Tadić, Hrvatski čestotni rječnik, 484) to 0,0003 dla przyimka proti oraz 0,0001 dla protivu, przy czym tylko w tym słowniku wymieniane są obie formy. Rječnik hrvatskoga jezika (Jure Šonje, red. Rječnik hrvatskoga jezika (Zagreb: Leksikografski zavod „Miroslav Krleža“; Školska knjiga, 2000)) nie odnotowuje żadnego z wariantów, z kolei tylko protivu występuje w słownikach Veliki rječnik hrvatskog standardnog jezika (Ljiljana Jojić, red. Veliki rječnik hrvatskoga standardnog jezika (Zagreb: Školska knjiga, 2015)) i Veliki rječnik hrvatskoga jezika (Vladimir Anić, Veliki rječnik hrvatskog jezika (Zagreb: Novi liber, 2003, CD-ROM), hasło: protivu).

${ }_{5}^{5}$ Branimir Belaj i Goran Tanacković Faletar, Kognitivna gramatika hrvatskoga jezika. Knjiga prva. Imenska sintagma i sintaksa padeža (Zagreb: Disput, 2014), 358, 399. Należy także dodać, że rekcja celownikowa jest pierwotna względem dopełniaczowej. W chorwackiej redakcji SCS formy protivb obok protivu oraz proti w znaczeniu kierunku oraz położenia
} 
Literatura przywołująca chorwacki przyimek protiv jest skąpa. Gramatyki nie poświęcają mu wiele uwagi i zazwyczaj jest on tylko wymieniany wśród innych przyimków w grupach powiązanych genetycznie, morfologicznie ${ }^{6}$, składniowo i semantycznie ${ }^{7}$. Najbardziej szczegółowa charakterystyka znajduje się w monografii Kazimierza Feleszki $^{8}$ analizującego funkcje składniowe i łączliwość przyimka oraz u Branimira Belaja i Gorana Tanackovicia Faletara ${ }^{9}$, którzy za pomocą metodologii semantyki kognitywnej opisują powiązania między znaczeniami nieprzestrzennymi a przestrzennymi przyimka.

Badania konfrontatywne przyimka protiv są jeszcze mniej liczne. Można tu wymienić przeprowadzone przez Ivanę Matas Ivanković ${ }^{10}$ odniesienie chorwackiego protiv do rosyjskiego против $\mathrm{w}$ domenie przestrzeni fizycznej. Badania przyimka protiv i jego polskich odpowiedników dotychczas nie przeprowadzono.

Aby poznać użycia przyimka protiv, należy sięgnąć do chorwackich źródeł leksykograficznych, które zawierają trzy lub cztery definicje. $\mathrm{Na}$ pierwszym miejscu wymieniane jest znaczenie spacjalne: ruch w kierunku przeciwnym do ruchu kogoś lub czegoś, we wszystkich słownikach opatrzone tymi samymi przykładami: ploviti protiv struje, trčati protiv vjetra ${ }^{11}$. Znaczenie lokatywne wymieniane jest tylko w niektórych źródłach i jako ostatnie, z kwalifikatorem ,archaizm“, za jego synonim zaś uznaje się przyimek nasuprot ${ }^{12}$. Pozostałe przytaczane $\mathrm{w}$ słownikach użycia wpisują się w relację kontraryjną. Z jednej strony jest tu mowa o wyrażaniu przeciwnego stanowiska, przeciwstawianiu, niezgadzaniu się z czymś, rywalizacji, nieprzyjacielskiej relacji czy konflikcie, z drugiej zaś - o sytuacji uniemożliwiania czegoś, ogra-

występowały właśnie z celownikiem (Jasna Vince, „Prostorni prijedložni izrazi u hrvatskom crkvenoslavenskom jeziku,“ Slovo, vol. 60 (2010): 814).

${ }^{6}$ Eugenija Barić, Mijo Lončarić, Dragica Malić, Slavko Pavešić, Mirko Peti, Vesna Zečević i Marija Znika, Hrvatska gramatika (Zagreb: Školska knjiga, 1997), 278. Autorzy ci uznają przyimek protiv za pierwotny.

${ }^{7}$ Josip Silić i Ivo Pranjković, Gramatika hrvatskoga jezika za gimnazije i visoka učilišta (Zagreb: Školska knjiga, 2005), 217; Ivo Pranjković, Druga hrvatska skladnja: Sintaktičke rasprave (Zagreb: Hrvatska sveučilišna naklada, 2001), 25.

${ }^{8}$ Kazimierz Feleszko, Sktadnia genetiwu $i$ wyrażeń przyimkowych z genetiwem $w$ języku serbsko-chorwackim. (Wrocław: Zakład Narodowy im. Ossolińskich, 1970), 170-172.

${ }^{9}$ Belaj i Tanacković Faletar, Kognitivna gramatika, 358-359.

${ }^{10}$ Ivana Matas Ivanković, Izražavanje prostora i vremena prijedlozima s genitivom u hrvatskom i ruskom jeziku. (Zagreb: Institut za hrvatski jezik i jezikoslovlje, 2014), 185-187.

${ }^{11}$ Jojić, red. Veliki rječnik, 1235; Šonje, red. Rječnik hrvatskoga jezika, 108; Anić, Veliki rječnik hrvatskog jezika, hasło: protiv.

${ }_{12}$ Šonje, red. Rječnik hrvatskoga jezika; Anić, Veliki rječnik hrvatskog jezika. 
niczania, redukowania szkodliwych skutków czegoś lub o ochronie przed czymś.

$\mathrm{Na}$ szczególną uwagę zasługują ustalone połączenia wyrazowe z przyimkiem protiv: biti protiv (čega, koga) w znaczeniu 'sprzeciwiać się oraz nemati ništa protiv 'zgadzać się, nie sprzeciwiać się', które przez źródła leksykograficzne interpretowane są jako frazeologizmy ${ }^{13}$.

Składnię przyimka protiv opisuje Feleszko ${ }^{14}$, wymieniając na pierwszym miejscu pozycję dopełnienia bliższego przy czasownikach oznaczających czynność „nieprzyjazną” względem osoby, zjawiska lub instytucji nazwanej w części imiennej wyrażenia przyimkowego, np. buniti se protiv + Gen., boriti se protiv + Gen. $Z$ kolei w odniesieniu do połączeń z czasownikami oznaczającymi czynność „neutralną” Feleszko mówi o modyfikowaniu tematu czasownikowego z zachowaniem roli pacjensa, np. govoriti protiv + Gen., raditi protiv $+\mathrm{Gen}$. Za nieliczne Feleszko uznaje pozycje okolicznika (np. przyzwolenia), w których wyrażenie przyimkowe ma znaczenie bardziej sprecyzowane i wynikające $\mathrm{z}$ kontekstu, przy tym nie wskazuje bezpośredniego obiektu czynności. Dość liczne są natomiast wyrażenia adnominalne przy rzeczownikach spokrewnionych etymologicznie z czasownikami partnerstwa lub obiektu, np. borba, boj, pełniące m.in. funkcję przydawki okolicznościowej. Autor wymienia także pozycję orzecznika przy łączniku biti, które według Feleszki są konkurencyjne dla czasowników protiviti se, suprotstavljati se.

Jak już wspomniano, celem badania jest ustalenie zasobu polskich ekwiwalentów chorwackiego przyimka protiv oraz sprawdzenie ich konkurencyjności. Za materiał badawczy posłużyło 111 par konstrukcji, w których wystąpiła prepozycja protiv w różnych pozycjach składniowych. Wszystkie poświadczenia pochodzą z prozatorskich tekstów literackich reprezentujących standardowy język współczesny, a opublikowane tłumaczenia wykonane były przez rodzimych użytkowników języka polskiego. Badanie ekwiwalencji, a szczególnie próba ustalenia konkurencyjności odpowiedników, wymagało wstępnej analizy materiału wyjściowego: określenia, jakie użycia pojawiły się w materiale, a także scharakteryzowania najistotniejszego prawo-, ale także lewostronnego kontekstu przyimka protiv. Informacje te uzupełniają dotychczasową wiedzę na temat chorwackiego przyimka.

\footnotetext{
13 Jojić, red. Veliki rječnik; Šonje, red. Rječnik hrvatskoga jezika.

${ }^{14}$ Feleszko, Sktadnia genetiwu, 170-172.
} 


\section{Znaczenia i łączliwość przyimka protiv w materiale badawczym}

Na podstawie analizy poszczególnych użyć badanego przyimka można stwierdzić, że protiv we współczesnym języku chorwackim jest wykładnikiem przede wszystkim relacji kontraryjnej. Na 111 konstrukcji wyjściowych relację tę wyrażało 109, a tylko jedno poświadczenie odnosiło się do domeny przestrzeni, oznaczając ruch ukierunkowany (veslati protiv vjetra $[$ Horvat - Besa $])^{15}$.

W prawostronnym otoczeniu przyimka przeważają desygnaty żywotne (75 poświadczeń, tj. około 68\%) nad nieżywotnymi (36-32\%). W pierwszej grupie najliczniejsze były rzeczowniki abstrakcyjne, a pojedyncze wypadki stanowiły rzeczowniki konkretne. Wyróżnić tu można semantyczne grupy zawierające nazwy związane ze sferą psychiczną człowieka, sferami emocji czy woli: volja, želja, uvjerenje, iznenađenje, ljubav, poštovanje, determiniranost, samoća, čulnost; nazwy chorób i dysfunkcji organizmu: prehlada, apatija, hunjavica, mrcvarenje, depresija, boginje, zarazna grlobolja, lijenost crijeva, prištici, kuga, smrtna bolest, smrt; nazwy szkodliwych działań ludzkich, np. aktów magicznych: werbalnych i niewerbalnych: kletva, urok; działań związanych z użyciem siły i agresją: rat, lov, tereor, revolucija; nazwy broni: tenk; nazwy szkodliwych dla przyrody i człowieka substancji: dim, ispušni plinovi, zagađenje; nazwy organizacji i wspólnot państwowych, religijnych ideologicznych: monarhija, kršćanstvo. Pozostałe rzeczowniki są różnorodne pod względem znaczenia i trudne do skategoryzowania.

W grupie desygnatów żywotnych znalazły się rzeczowniki osobowe (14), w tym pospolite (7) i nazwy własne (7), rzeczowniki nieosobowe (5), nazwy zwierząt: krava, vuk, krpelj, buha, komarac, vrabac. Liczną grupę stanowiły zaimki osobowe (16).

Jak już była mowa, nadrzędnikiem wyrażenia protiv + Gen. może być czasownik lub rzeczownik. W zebranym materiale przeważało występowanie przy czasownikach (79 poświadczeń, 71\%), w tym przy czasowniku imati w połączeniu sfrazeologizowanym (9 poświadczeń) i przy łączniku biti jako orzecznik w orzeczeniu imiennym (10). Czasowniki mogły mieć znaczenie czynności nieprzyjaznej bądź nie-

\footnotetext{
${ }^{15}$ Ivana Matas Ivanković w przeprowadzonym badaniu korpusowym nie odnotowała żadnego użycia przestrzennego przyimka protiv (Matas Ivanković, Izražavanje prostora i vremena, 185-187).
} 
korzystnej dla osoby, zjawiska, instytucji nazwanej w części imiennej wyrażenia przyimkowego. Wysoką frekwencję miały czasowniki oznaczające walkę, złe zamiary, agresję, np. częsty boriti se, dalej tući se, urotiti, protestirati, buniti se, provaliti, dizati se, także agresje werbalną: siktati, iznositi optužbe, vikati. Czasowniki nazywane przez Feleszkę ${ }^{16}$ „,neutralnymi”, które dopiero z wyrażeniem przyimkowym nabierają znaczenia negatywnej czynności, walki, przeciwstawiania się, to np. ići, krenuti, raditi, govoriti, poduzeti.

Rzeczownik jako nadrzędnik wyrażenia protiv + Gen. jest notowany rzadziej (32 poświadczenia, około 29\%). Wystąpiły tutaj znaczenia związane z walką (w tym rzeczowniki odczasownikowe), przeciwstawianiem się: borba, borac, križarski pohod; zapobieganiem czemuś lub ochroną: lijek, štit, molitvica, cijepljenje, amajlija, ale także mogły mieć znaczenie neutralne, które, podobnie jak czasowniki, znaczenia kontraryjności nabierały w połączeniu z wyrażeniem protiv+Gen.

\section{Badanie ekwiwalencji}

W badaniu konfrontatywnym, które zakłada ustalenie polskich odpowiedników przekładowych chorwackiego przyimka protiv $+\mathrm{Gen}$., w pierwszej kolejności wymienione zostaną ekwiwalenty przyimkowe oraz wskazane ograniczenia związane z wyborem takiego ekwiwalentu. Analizowane będą m.in. cechy semantyczne lub ograniczenia w łączliwości. Ponadto zbadana zostanie frekwencja danego ekwiwalentu. $\mathrm{Na}$ końcu omówione zostaną przekłady nieprzyimkowe, w których dochodzi do transpozycji wyrażenia przyimkowego na inne środki językowe.

Wśród 111 polskich ekscerptów wystąpiło 9 ekwiwalentów przyimkowych: przeciw(ko)+Dat. (65 poświadczeń), $z+$ Ins. (13), wbrew+Dat. (8), na+Acc. (4), od+Gen. (3), dla+Gen. (2), na przekór+Dat. (1), przed+Ins. (1), pod+Acc. (1). Ponadto poszczególne konstrukcje z przyimkiem protiv + Gen. wyrażone były innymi środkami (13). Procentowy udział poszczególnych odpowiedników w całości korpusu pokazuje poniższy wykres. Podane wartości zostały zaokrąglone.

\footnotetext{
${ }^{16}$ Feleszko, Sktadnia genetiwu, 171.
} 


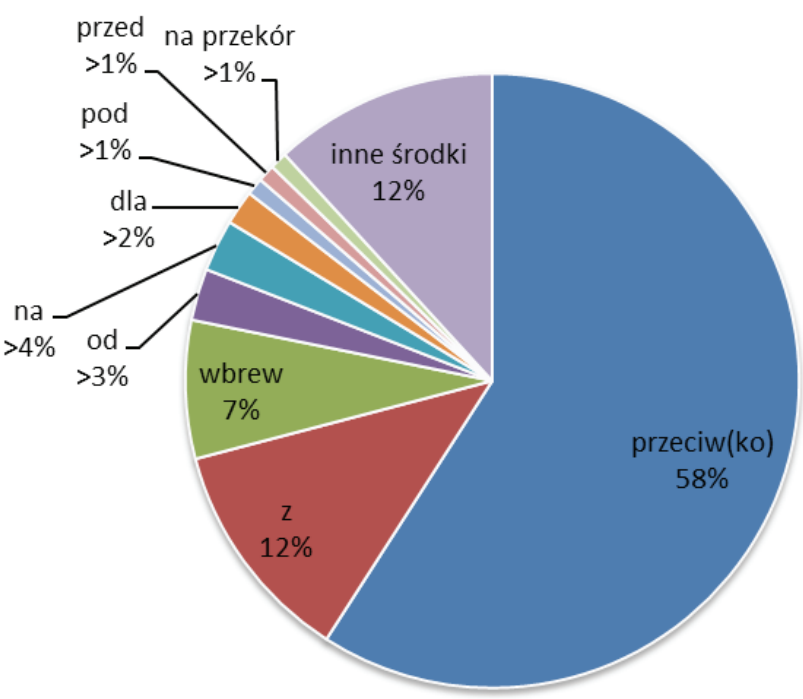

\begin{abstract}
Wykres 1. Udział poszczególnych polskich odpowiedników tłumaczeniowych chorwackiego przyimka protiv w korpusie badawczym (opracowanie własne).
\end{abstract}

\title{
PROTIV+Gen. > PRZECIW(KO)+Dat. (65 poświadczeń; 58\%)
}

Najwyższą frekwencję miał genetycznie pokrewny z przyimkiem chorwackim ekwiwalent przeciw(ko) (65) pochodzący od formy przymiotnikowej protiv 'przeciwny'17, lub od rzeczownika ${ }^{18}$. Formy przeciw i przeciwko traktuję jako warianty formalne ${ }^{19}$ i omawiam razem, warto jednak zaznaczyć, że forma przeciwko miała w korpusie więcej

\footnotetext{
${ }^{17}$ Wiesław Boryś, Stownik etymologiczny języka polskiego (Kraków: Wydawnictwo Literackie, 2005), 488; Beata Milewska, Stownik polskich przyimków wtórnych (Gdańsk: Wydawnictwo Uniwersytetu Gdańskiego, 2003), 90; Milewska (Milewska, Stownik polskich przyimków wtórnych, 90) podaje, że w polszczyźnie przyimek ten obecny jest od XVI wieku. Pochodzenie przyimka związane jest z prasłowiańską formą przymiotnikową *pretivъ 'znajdujący się po drugiej stronie, leżący naprzeciw, przeciwległy; przeciwstawny, odmienny; nieprzyjemny, nieprzyjazny’ (Boryś, Stownik etymologiczny języka polskiego, 488).

${ }^{18}$ Zdzisława Krążyńska, Staropolskie konstrukcje z przyimkami. Część V (Poznań: Poznańskie Studia Polonistyczne, 2012), 17.

${ }^{19}$ Forma przeciwko odnotowana przez słowniki języka polskiego odsyła do formy przeciw (Stanisław Dubisz, red. Uniwersalny stownik języka polskiego (Warszawa: PWN, 2004. CD-ROM); Bogusław Dunaj, red. Współczesny słownik języka polskiego (Warszawa: Langenscheidt, 2009. CD ROM)). Jako warianty omawia je także Lesz-Duk (Maria Lesz-Duk, Czasowniki o składni przyimkowej w języku polskim (Częstochowa: Wydawnictwo Wyższej Szkoły Pedagogicznej w Częstochowie, 1988), 292) i Wielki słownik języka polskiego (Piotr Żmigrodzki, red. Wielki stownik języka polskiego (Instytut Języka Polskiego PAN), dostęp 5 lipca 2020, https://wsjp.pl/index.php?id_hasla=30683\&id_znaczenia=4751131\&l=21\&ind=0.
} 
poświadczeń (38). W języku polskim przyimek ten łączy się z celownikiem $^{20}$.

Milewska określa przyimek przeciw(ko) jako wykładnik relacji kontraryjnej, który oznacza wrogość i działanie przeciwne ${ }^{21}$. Wielki słownik języka polskiego odnotowuje dwa typy znaczeń przyimka przeciw(ko). W pierwszym, ilustrowanym przykładem lekarstwo przeciw grypie, przyimek jest „wykładnikiem ustalania relacji”, i definiowany jako „stan rzeczy, o którym mówi nadawca, jest sprzeczny z sytuacją, w której to, o czym mowa, mogłoby istnieć/dziać się bez przeszkód". Sama definicja, ale też sugerowany synonim wbrew nie oddają znaczenia prepozycji przeciw( $k o$ ) w przytaczanym przez słownik przykładzie. Drugie użycie określone jest jako „wykładnik relacji wzajemności" z reprezentatywnym przykładem walczyć przeciw sobie według definicji desygnuje przeciwników w działaniu ${ }^{22}$.

Bardziej rozbudowane definicje słownikowe wyróżniają od 4 do 10 użyć przyimka, z których większość stanowi egzemplifikacje znaczenia kontraryjnego. Najbardziej szczegółowo przyimek opisany jest Innym słowniku języka polskiego ${ }^{23}$, który wymienia następujące użycia: niezgadzanie się na coś lub z czymś; powodowanie, aby jakiejś osobie stało się coś złego; zapobieganie lub usuwanie czegoś złego; bycie zagrożeniem dla czegoś dobrego; uważanie, że czegoś nie powinno być lub że nie należy czegoś robić; wyrażanie zastrzeżeń do danej osoby lub danej rzeczy; współzawodniczenie osób lub drużyn; posuwanie się w odwrotnym kierunku niż desygnat celownika ${ }^{24}$. Słownik ten wymienia także konstrukcje z elipsą celownika: głos przeciw, argument przeciw.

Jak można zauważyć, znaczna część użyć polskiego przyimka $\operatorname{przeciw}(k o)$ pokrywa się z użyciami chorwackiego protiv. Opierając się na definicjach słownikowych, trudno jest jednak precyzyjnie ustalić podobieństwa i różnice, gdyż definicje mogą się różnić metodą i szczegółowością opisu.

\footnotetext{
${ }^{20}$ Źródła podają, że dawniej przyimek przeciw mógł się niekiedy łączyć z dopełniaczem (Witold Doroszewski, red. Stownik języka polskiego, dostęp 14 kwietnia 2019, https://sjp. pwn.pl/doroszewski/przeciw;5482821.html).

${ }^{21}$ Milewska, Stownik polskich przyimków wtórnych, 90; Beata Milewska, Przyimki wtórne we wspótczesnej polszczyźnie (Gdańsk: Wydawnictwo Uniwersytetu Gdańskiego, 2003), 120. ${ }_{22}$ Żmigrodzki, red. Wielki słownik języka polskiego, dostęp 5 lipca 2020, https://wsjp.pl/ index.php?id_hasla $=30683 \&$ ind $=0 \&$ w_szukaj=przeciw.

${ }_{23}$ Mirosłw Bańko, red. Inny słownik języka polskiego (Warszawa: PWN, 2000), 292.

${ }^{24}$ Uniwersalny słownik języka polskiego (Dubisz, red. Uniwersalny słownik języka polskiego) znaczenie spacjalne uznaje za przestarzałe.
} 
Na podstawie badań łączliwości ekwiwalentu przeciw(ko) można stwierdzić, że wystąpił on przy czasownikach (48 poświadczeń - 74\%) oraz przy rzeczownikach, których było mniej $(17-26 \%)$.

W wypadku konstrukcji z lewostronnym czasownikiem odnotowujemy stałe połączenia z czasownikami biti - być i imati - mieće ${ }^{25}$, które w obu językach pokrywają się pod względem znaczenia:

Svi su uokolo protiv njega... [Marinković - Kiklop] Wszyscy dookoła byli przeciwko niemu...;

Svi smo bili na istoj strani, protiv zagađenja... [Rudan - Ljubav...] Wszyscy byliśmy przeciw zanieczyszczeniom...;

...nije imao ništa protiv janjetine s ražnja... [Jergović - Freelander] ...nie miat nic przeciwko jagnięcinie z rożna...;

Nema on ništa protiv mene... [Marinković - Kiklop]

Nie ma nic przeciwko mnie...

W obu językach przy tych czasownikach rzeczownik poprzyimkowy może być pominięty ${ }^{26}$, ale jest czytelny z kontekstu:

...čuj, nemam ništa protiv... [Marinković - Kiklop] ....stuchaj, nie mam nic przeciwko...

Oba typy konstrukcji stanowiły znaczną część grupy ekwiwalentu przeciw: 8 poświadczeń imati protiv - mieć przeciw(ko) i 10 biti protiv - być przeciw(ko).

Inne czasowniki w tej grupie oznaczały działania związane $\mathrm{z}$ agresją i walką z przeciwnikiem, złe nastawienie względem desygnatu celownika, np. boriti se - walczyć, urotiti se - sprzysiac się, dizati

\footnotetext{
${ }^{25}$ W źródłach wyrażenia być przeciw+Dat., mieć+Acc. przeciw+Dat. bywają klasyfikowane jako frazeologizmy (Dubisz, red. Uniwersalny stownik języka polskiego, hasło: przeciw, mieć I, Doroszewski, Stownik języka polskiego, hasło: przeciw, https://sjp.pwn.pl/doroszewski/przeciw;5482821.html). Zwrot mieć co przeciw, przeciwko czemu, komu w Słowniku frazeologicznym języka polskiego definiowane jest jako 'sprzeciwiać się czemu' i 'móc koтu co zarzucić, czuć niechęć z powodu czego' (Stanisław Skorupka, Stownik frazeologiczny języka polskiego. Tom 2 (Warszawa: Wiedza Powszechna, 1985), 439).

${ }^{26}$ Por. Iwona Kosek, Przyczasownikowe frazy przyimkowo-nominalne $w$ zdaniach wspótczesnego języka polskiego (Olsztyn: Wydawnictwo Uniwersytetu Warmińsko-Mazurskiego, 1999), 83.
} 
se - podnosić się, buniti se - buntować się, protestirati - protestować, vikati - krzyczeć, ustati - podnieść się ${ }^{27}, \mathrm{np}$.:

...protestiramo protiv nečuvenog nasilja... [Desnica - Proljeća...] ...protestujemy przeciw niestychanemu gwaltowi...;

Sve se urotilo protiv nje. [Kušan - Zagonetni...]

Wszystko się przeciwko niej sprzysięgło.

Wystąpiły tu także konstrukcje z czasownikami ,neutralnymi”, które w połączeniu z wyrażeniem przyimkowym protiv + Gen. i przeciw + Dat. nabierały znaczenia szkodzenia komuś, np. raditi - pracować, poduzeti - przedsięwziać:

Moj je um (...) radio protiv mene. [Rudan - Ljubav...]

Mój umyst (...) pracowat przeciwko mnie.;

...ništa nije poduzela protiv nastavnika tjelesnoga... [Jergović Freelander]

...nic nie przedsięwzięta przeciw nauczycielowi wychowania fizycznego...

W wypadku czasowników przechodnich istotna była także semantyka dopełnienia bliższego, np. napisati pamflet - napisać pamflet lub dla predykatów analitycznych ich ogólne znaczenie, np. iznositi optužbe - wnosić oskarżenia:

Ovo nejasno i kalno pronašao sam u jednom pamfletu koji je protiv slikara napisao njegov nekadašnji prijatelj. [Mićanović Enformel]

To niejasne i plugawe odnalaztem $w$ pewnym pamflecie, który napisat przeciwko malarzowi jego dawny przyjaciel.

W grupie ekwiwalentu przeciw(ko) wystąpiły również konstrukcje z czasownikami ruchu, których nie można uznać za spacjalne. Oznaczają tu one podjęcie ataku, konfrontacji, a celownik wskazuje na stronę w konflikcie, przeciwnika w walce ${ }^{28}$, np.:

\footnotetext{
${ }^{27}$ Przytaczane polskie odpowiedniki czasowników podane są na podstawie przekładów i przeważnie nie wyczerpują wszystkich znaczeń czasownika oryginalnego.

${ }^{28}$ Pisze o tym także Matas Ivanković (Matas Ivanković, Izražavanje prostora i vremena, 185).
} 
On je htio da svi muslimani krenu protiv kršćanstva. [Kušan Zagonetni...]

Chciat on zjednoczyć wszystkich muzutmanów i wyruszyć przeciwko chrześcijanom.

Idem goloruk protiv zmaja kao onaj junak biblijski... [Marinković - Kiklop]

Ide $z$ gotymi rękami przeciwko smokowi, jak ten bohater biblijny...

Z kolei w poniższym przykładzie konstrukcja łączy pierwotne znaczenie ruchu ze znaczeniem ataku, ruszaniem w stronę oddziałów wroga w celu podjęcia walki.

Kod Kutna, kod Kutna su oni kopljima, konjanici (...) išli protiv Teutona kao u srednjem vijeku Boleslav Krivousti... [Marinković - Kiklop]

Pod Kutnem, pod Kutnem oni z lancami, ułani (...) szli przeciwko Teutonom jak w średniowieczu Bolesław Krzywousty...

Desygnat argumentu w celowniku występującego przy czasowniku mógł być żywotny lub nieżywotny. Jeśli wystąpiły tu pewne ograniczenia, związane są one ze znaczeniem konkretnego czasownika lub całej konstrukcji, np. ići protiv + Gen. i iść przeciwko+Dat. z reguły wystąpią $\mathrm{z}$ celownikiem żywotnym lub personifikowanym, np. kršćanstvo, w thumaczeniu jako rzeczownik osobowy chrześcijanie.

W materiale wystąpił także jeden czasownik, którego znaczenie z wyrażeniami protiv i przeciw z nazwą choroby można zinterpretować jako zapobieganie tej chorobie: cijepiti se-szczepić się.

W grupie nadrzędników rzeczownikowych liczne są rzeczowniki konkretne o znaczeniu zapobiegania, naprawiania, ale też „neutralne”, podczas gdy desygnat argumentu w celowniku oznaczał coś szkodliwego, niekorzystnego:

štit protiv klevete [Marinković - Kiklop]

tarcza przeciwko oszczerstwu;

lijek protiv (...) smrtne bolesti [Desnica - Proljeća...]

lekarstwo przeciw (...) śmiertelnej chorobie; 
jesenje piće, protiv hunjavice [Marinković - Kiklop]

jesienny napój przeciwko katarowi;

prašak protiv buha [Jergović - Freelander]

proszek przeciw pchłom.

Nadrzędniki o znaczeniu walki stanowiły tu mniejszość: borbawalka, križarski pohod -wojna krzyżowa:

Eto tko se najednom našao na čelukrižarskog pohoda protiv socijalističkih zemalja. [Hotvat - Besa]

Oto kto naraz znalazt się na czele wojny krzyżowej przeciwko krajom socjalistycznym.

W tłumaczeniach zaobserwować też można było zamianę członu nadrzędnego $\mathrm{z}$ czasownika na rzeczownik dewerbatywny lub odwrotnie:

...riješio bih učas lijevom nogom sve u vašu korist, jer je to isto tako beznačajno kao i boriti se protiv vas. [Desnica - Proljeća...] ...jednym kiwnięciem palca załatwiłbym wszystko na pani korzyść, bo to jest tak samo nieważne jak walka przeciwko wam.

PROTIV+Gen. > Z+Ins. (13: 12\%)

Zdecydowanie niższą frekwencję miał polski ekwiwalent $z+$ Ins., wieloznaczny przyimek pierwotny, który oznacza relację towarzyszenia, współwystępowania, współuczestniczenia, a ponadto celu, skutku, kierunku, podlegania działaniu lub stanowi oraz wskazuje na okres rozwijania się jakiejś czynności ${ }^{29}$. Jako ekwiwalent chorwackiego protiv wystąpił przeważnie (11 poświadczeń) przy wyrazach oznaczających walkę jako przyimek regowany, tj. przy czasownikach boriti se - walczyć, tući se - bić się lub rzeczownikach borba - walka, przyjmując znaczenie współuczestniczenia, ale jednocześnie ze względu na znaczenie wyrazu nadrzędnego desygnat podrzędnika w tych strukturach wskazuje na żywotnego przeciwnika lub okoliczności, przeciw którym agens występuje lub stara się je znieść, np.:

${ }^{29}$ Dunaj, red. Wspótczesny stownik języka polskiego, hasło: z II. 
Salih F. se toga dana tukao protiv pola logora. [Jergović - Dijagnoza]

Tego dnia Salih F. bit się z polowa obozu.

Ne bih volio biti kao žena (...) koja se bori protiv muževljeve ljubavi prema zvijezdama... [Mićanović - Trajekt]

Nie chciałbym być jak kobieta (...), która walczy z miłościa męża do gwiazd...

Pozostałe dwa użycia wystąpiły przy polskim czasowniku zrobić i z elipsą czasownika w języku chorwackim:

Strašno je što ne mogu ništa protiv toga... [Ferić - Blues...]

Najgorsze jest to, że nic nie moge z tym zrobić...

W strukturach wyjściowych obecność przyimka protiv niesie znaczenie kontraryjne, w polskiej strukturze zaś wyrażenie przyimkowe wskazuje na nieżywotny obiekt czynności, a ewentualną informację o przeciwstawianiu czerpiemy z innych elementów zdania (zdanie nadrzędne i orzeczenie najgorsze jest) oraz z szerszego kontekstu.

PROTIV+Gen. > WBREW+Dat. (8: 7\%)

Przyimek wtórny wbrew+Dat. zaliczany jest do przyimków o funkcji przyczynowej przyzwolenia. Wskazuje na przeciwstawną okoliczność, a jego synonimy to pomimo, na przekór, bez względu $n a^{30}$. Milewska wymienia ponadto sporadyczne silnie uwarunkowane kontekstowo użycia o funkcji warunkowej oraz z zaimkiem zwrotnym sobie pokazującym relacje sposobu ${ }^{31}$.

Ekwiwalent wbrew w badanym materiale wystąpił w 7 na 8 poświadczeń $\mathrm{w}$ połączeniu $\mathrm{z}$ rzeczownikiem wola oraz jednokrotnie $\mathrm{z}$ rzeczownikiem przekonania i wyraża przeciwstawną $\mathrm{w}$ ocenie mówiącego okoliczność. Agens jest osobowy, z kolei nadrzędne dla wyrażenia przyimkowego czasowniki oznaczają różnorodne czynności, np. skočiti - zeskoczyć, govoriti - mówić, ostati - zostać i nie konotują przyimkowego podrzędnika:

30 Dunaj, red. Współczesny słownik języka polskiego, hasło: wbrew.

${ }^{31}$ Milewska, Słownik polskich przyimków wtórnych, 100-101. 
Dakako, da su me noge nosile protiv moje volje... [Furtinger Trebam...]

Oczywiście nogi niosty mnie wbrew mojej woli...;

Isplati se vikati i protiv uvjerenja. [Marinković - Kiklop]

Opłaci się krzyczeć nawet wbrew przekonaniom.

PROTIV $+\mathrm{G}>\mathrm{NA}+\mathrm{Acc}(4:>3 \%)$

Kolejny ekwiwalent to wieloznaczny przyimek pierwotny $n a+$ Acc. z podstawowym znaczeniem spacjalnym. W użyciach ekwiwalentnych do chorwackiego przyimka protiv przyimek na oznacza relację wywierania nacisku, ataku na desygnat biernika, który jest tu przeciwnikiem. W badanych przykładach zawarta jest sytuacja fizycznego oraz werbalnego ataku ${ }^{32}$ :

- A što da idem s malim stvarima protiv tenkova? [Marinković Kiklop]

- A co, mam iść z matymi sprawami na czotgi?

...siktala je protiv njih, i tukla Karla... [Jergović - Freelander]

...sarkała na nich i biła Karla...

Drugie użycie przyimka $n a+$ Acc ma znaczenie zapobiegania czy przeciwdziałania czemuś niekorzystnemu ${ }^{33}$ :

Ali znate šta vam je najbolje protiv prehlade? [Jergović - Freelander]

Ale wie pan, co jest najlepsze na przeziębienie?

Znaczenie to ilustruje także poniższy przykład, w którym tłumacz zastosował ponadto translatorską technikę konkretyzacji:

...i ovdje se (...) vidjelo da su duge bijele trake vezane za stabla, protiv vrabaca, protiv uroka ili kao znak da je netko umro. [Slamnig - Bolja...]

\footnotetext{
32 Por. Renata Przybylska, Polisemia przyimków polskich w świetle semantyki kognitywnej (Kraków: Universitas, 2002), 327-330.

${ }_{33}$ Kosek $n a+$ Acc. traktuje jako równoważnik pozycyjny frazy przeciwko+Dat. w zdaniach konstytuowanych przez czasowniki uodpornić czy szczuć (Kosek, Przyczasownikowe frazy przyimkowo-nominalne, 83 ), tj. wpisujących się w znaczenia zapobiegania lub szkodzenia.
} 
...widać było przywiązane do drzew dtugie białe taśmy, strach na wróble, znak, że ktoś umart, albo dla odczynienia uroków.

PROTIV+Gen. $>$ OD + Gen. $(3:>3 \%)$

Jako bardzo rzadki odpowiednik wystąpił pierwotny przyimek $o d+$ Gen., który jest kolejnym wieloznacznym ${ }^{34}$ przyimkiem z ablatywnym znaczeniem prototypowym. $\mathrm{W}$ badanym materiale odnotowany został w grupach imiennych, w których rzeczownik nadrzędny oznacza przedmiot zabezpieczający przed zjawiskiem określanym za pomocą poprzyimkowego rzeczownika $\mathrm{w}$ dopełniaczu. Uniwersalny słownik języka polskiego ${ }^{35}$ użycie to określa jako synonimiczne do jednego ze znaczeń przyimka przeciw:

...promrmlja neki pozdrav kao molitvicu protiv uroka. [Marinković - Kiklop]

...wyjąkat jakieś pożegnanie jak zaklęcie od uroku.

W jednym z przykładów znaczenie polskiego ekwiwalentu od zostało poszerzone o imiesłów przymiotnikowy informujący o zapobieganiu czemuś złemu, regujący wspomniane wyrażenie przyimkowe:

Crkvica je izdaljega izgledala lijepo i vrlo staro - pretpostavljam da je bila zavjetna kapela protiv kuge... [Slamnig - Bolja...] Kościótek z odległości wydawat się tadny i bardzo stary przypuszczam, ze to była kaplica fundacyjna chroniąca od dżumy...

PROTIV+Gen. $>$ DLA+Gen. $(2:>2 \%)$

Prepozycja dla+Gen. wystąpiła w dwóch tłumaczeniach przyimka protiv. Ten wieloznaczny polski przyimek $\mathrm{w}$ materiale badawczym niósł dwa znaczenia. W pierwszym przytoczonym przykładzie było to znaczenie celu, w którym referent materialny został zamieniony zdarzeniowym:

\footnotetext{
34 Wspótczesny słownik języka polskiego (Dunaj, red. Współczesny słownik języka polskiego, hasło: dla ) czy Uniwersalny stownik języka polskiego (Dubisz, red. Uniwersalny słownik języka polskiego, hasło: dla) wymieniają aż 16 funkcji znaczeniowych.

${ }^{35}$ Dubisz, red. Uniwersalny słownik języka polskiego, hasło: od.
} 
...i ovdje se (...) vidjelo da su duge bijele trake vezane za stabla, protiv vrabaca, protiv uroka ili kao znak da je netko umro. [Slamnig - Bolja...]

...widać byto przywiazane do drzew dtugie białe taśmy, strach na wróble, znak, że ktoś umart, albo dla odczynienia uroków.

W drugim przykładzie w tłumaczeniu użyte było połączenie sfrazeologizowane $^{36} \mathrm{z}$ żywotnym referentem w dopełniaczu. Pełni on rolę punktu docelowego dla emocji lub sądu:

Ali jedan od njih kaže, ne bojte se, ja imam pilu, i oni se umirili. Misle, doduše, što će pila protiv vuka? [Marinković - Kiklop] Ale jeden z nich mówi, nie bójcie się, mam piłe, i oni uspokoili się. Myśla, a jednak co znaczy piła dla wilka?

Pomimo że polskie tłumaczenie przekazuje ideę zawartą w zdaniu chorwackim, nie uwzględnia ono relacji przeciwstawności sygnalizowanej przez chorwacki przyimek. Podobnie jest w pierwszym przykładzie.

PROTIV+Gen. > NA PRZEKÓR+Dat. (1: > 1\%)

Tylko jeden raz użyty był jako ekwiwalent przyimek wtórny $n a$ przekór+Dat. Zaliczany jest on do wykładników relacji kontraryjnej i wskazuje na działanie przeciwne czyjejś woli lub okolicznościom, podobnie jak jego synonim wbrew $^{37}$ :

...radi sve protiv svojih želja... [Novak — Miris]

....wszystko robi na przekór własnym chęciom...

PROTIV+Gen. > PRZED+Ins. (1: > 1\%)

Ekwiwalent przed+Ins. to pierwotny przyimek z prototypowym znaczeniem lokatywnym, w badanym kontekście występujący w jednym z użyć pochodnych, w którym desygnat narzędnika oznacza źródło

\footnotetext{
${ }^{36}$ Skorupka, Stownik frazeologiczny języka polskiego, 862.

${ }^{37}$ Milewska, Stownik polskich przyimków wtórnych, 51; Lesz-Duk, Przyimki wtórne w języku polskim, 130; Czesław Lachur, Polskie przyimki wtórne i jednostki o funkcji przyimkowej w uzyciu realnym. Materiaty do stownika (w zestawieniu z językiem rosyjskim). Tom 1 (Kępa: Wydawnictwo Nowik sp. j., 2019), 294.
} 
zagrożenia, a wyraz nadrzędny dla wyrażenia przyimkowego oznacza reakcję obronną na nie ${ }^{38}$ :

A vi ste se osigurali protiv tih iznenađenja. [Marinković - Kiklop] A pan się ubezpieczyt przed tymi niespodziankami?

PROTIV+Gen. $>$ POD+Acc. $(1:>1 \%)$

Podobnie niską frekwencją cechował się ekwiwalent pod+Acc., przyimek pierwotny z prototypowym znaczeniem spacjalnym. W przytoczonym kontekście wskazuje na cel przestrzenny ruchu przeciwstawnego, połączonego z oporem ${ }^{39}$ :

Do obale je daleko, treba veslati protiv vjetra... [Horvat - Besa]

Do brzegu daleko, trzeba wiostować pod wiatr...

INNE ŚRODKI (13: 12\%)

$\mathrm{Na}$ tle wymienionych ekwiwalentów przyimkowych niemałą grupę (13) stanowily inne sposoby przedstawiania treści chorwackiego wyrażenia protiv+Gen. Były to przykłady, w których konstrukcja przyimkowa transponowana jest na różne środki morfologiczne i składniowe. Znaczenie kontraryjne z oryginalnego przyimka w tłumaczeniu przeniesione było do czasownika lub, znacznie rzadziej, rzeczownika lub przymiotnika ${ }^{40}$ :

Odabrala je uzorak koji je podsjećao na grb ili na znamen protiv uroka... [Slamnig - Bolja...]

Wybrata tez emblemat, który przypominat herb albo znak odczyniajacy uroki...

...jedan čudotvorni krem protiv prištića ... [Desnica - Proljeća...]

...cudowny krem usuwający pryszcze...

Jebeni borci protiv rata! [Rudan - Ljubav...]

Jebani przeciwnicy wojen!

\footnotetext{
${ }^{38}$ Przybylska, Polisemia, 401.

39 Dunaj, red. Współczesny słownik języka polskiego, hasło: pod.

${ }^{40} \mathrm{O}$ transpozycji części mowy w tłumaczeniu pisze Ivir (Ivir, Teorija i tehnika prevođenja, 153).
} 
...umorne majke koje su pred izlazak popile jednu od ovih tajnovitih tableta protiv depresije i stresa... [Mićanović - Trajekt] ...zmęczone matki, które przed wyjściem zażyly jedna z tych tajemniczych tabletek antydepresyjnych $i$ antystresowych...

W dwóch ostatnich przykładach relacja kontraryjna została przeniesiona do prefiksu rzeczownika i przymiotnika $w$ grupach imiennych.

Wyrażenie przyimkowe transponowane bywa także na zdanie podrzędne:

...profesor Karlo Adum je nakon poraza, kao nakon sprovoda, morao protiv uroka s policajcem Stipom na piće... [Jergović Freelander]

...profesor Adum po przegranym meczu, jak po pogrzebie, żeby odwrócić urok, poszedt z policjantem Stipem na jednego.

W innym tłumaczeniu doszło do redukcji referentu, oznaczonego w oryginale wyrażeniem protiv $+\mathrm{Gen}$. :

Naravno da ne možeš ništa protiv toga-odgovorila mu je Leajer je ljubav kemija. [Ferić - Blues...]

Pewnie, że nic nie możesz zrobić - odpowiedziała mu Lea - bo mitość to chemia.

\section{Podsumowanie}

Przeprowadzone badanie pokazało, że język polski dysponuje znaczną liczbą przyimków, które w odpowiednich kontekstach są ekwiwalentne dla chorwackiego przyimka protiv + Gen. Za główny ekwiwalent prepozycji protiv należy uznać genetycznie powiązany przyimek przeciw(ko)+Dat., na co wskazuje jego wysoka frekwencja na tle innych odpowiedników (59\% wszystkich poświadczeń), tożsamość relacji semantycznych z przyimkiem protiv z wyjątkiem relacji spacjalnej oraz takie same wymagania dotyczące kontekstu prawo- i lewostronnego, włączając podobieństwo $\mathrm{w}$ stosunku procentowym nadrzędników werbalnych i imiennych (protiv 71\%: 29\%, przeciw $(k o)$ 74\% : 26\%). Na uwagę zasługuje też pokrywanie się połączeń sfrazeologizowanaych w obu językach. 
Użycie pozostałych odpowiedników jest statystycznie rzadsze oraz związane $\mathrm{z}$ ograniczeniami natury semantycznej lub w łączliwości prawo- lub lewostronnej, w tym rekcji wyrazów nadrzędnych. Można zaobserwować, że niektóre z polskich odpowiedników przekładowych obsługują tylko jedno z użyć relacji kontraryjnej, np. zapobieganie czemuś, redukowanie skutków szkodliwych działań: wyrażenie od+Gen. przy rzeczownikach i czasowniku chronić lub przed+Ins. Użycie, w którym wskazuje się na działanie przeciwne czyjejś woli lub okolicznościom, w języku polskim realizowały wyrażenia wbrew+Dat. i na przekór+Dat. Z kolei przyimek pod+Acc. z czasownikiem ruchu desygnował cel przestrzenny ruchu przeciwstawnego, połączonego z oporem.

Niektóre z odpowiedników tekstowych nie zawierały relacji kontraryjnej, lecz przedstawiały sytuację w zmodyfikowany sposób. Przykład może stanowić ekwiwalent $z+$ Ins., mający w przytoczonych zdaniach znaczenie współuczestnika, ale nie przeciwnika. Znaczenie przeciwnika wynika jednak z treści wyrazu nadrzędnego, który reguje wyrażenie przyimkowe, np. walczyć, walka, bić się i zawiera informację o przeciwdziałaniu członów relacji. Przyimki przeciw(ko) i $z$ nie są bliskoznacznikami ${ }^{41}$. Podobnie wyrażenie $n a+$ Acc., które z czasownikami ruchu oznacza atak na kogoś, nie zawiera znaczenia przeciwstawiania. Prawdopodobnie wpływa to na postrzeganie tej struktury za leksykalnie mniej wyrazistą od synonimicznej z wyrażeniem przeciw(ko)+Dat. ${ }^{42}$. Przykłady z przyimkami $d l a+$ Gen. wskazujące na cel lub punkt docelowy także ilustrują zjawisko nieuwzględnienia przez tłumacza relacji kontraryjnej na rzecz innych relacji.

Odwrotną sytuację obserwujemy w nieprzyimkowych odpowiednikach przekładowych chorwackiego protiv, w których zachodzi transpozycja znaczenia przeciwstawiania do innych niż przyimkowe morfologicznych i syntaktycznych środków językowych. Pokazuje to mnogość możliwości wyrażania tej samej treści różnymi formami, które, jak sądzę, miały podnieść wartość stylistyczną przekładu.

Ostatni wniosek związany jest ze słownikowym przedstawieniem chorwackiego przyimka protiv. Wobec niezwykle rzadkiego użycia tej prepozycji w znaczeniu ruchu ukierunkowanego sugeruję, żeby znaczenie to znalazło się na dalszej pozycji na liście użyć tego przyimka,

\footnotetext{
${ }^{41}$ Sławomir Werwiński, „Czy przyimek ogólnorelacyjny $w$ stosunku do jest równoznaczny z jednostkami $w$ odniesieniu do i w porównaniu z?" Linguistica Copernicana, vol. 4, no. 2 (2010): 165-166.

42 Przybylska, Polisemia, 329.
} 
nie zaś na pierwszym, jak ma to miejsce w przytaczanych słownikach języka chorwackiego.

Wyniki przeprowadzonej analizy mogą mieć znaczenie praktyczne, wpisując się w nurt językoznawstwa stosowanego, ale także teoretyczne. Pozyskane w badaniu dane mogą zostać wykorzystane do dydaktyki oraz praktyki tłumaczeniowej oraz przy opracowywaniu doskonalszych słowników przekładowch lub translatorów elektronicznych. Jednoczesnie dzięki spojrzeniu na dany język przez pryzmat drugiego języka poszerzana jest wiedza o systemach językowch badanych języków (plan langue), w połączeniu zaś z innymi badaniami szczegółowymi tworzona jest także podstawa do wniosków natury typologicznej.

\section{Bibliografia}

Anić, Vladimir. Veliki rječnik hrvatskog jezika. Zagreb: Novi liber, 2003. CD-ROM.

Bańko, Mirosłw, red. Inny stownik języka polskiego. Warszawa: PWN, 2000.

Barić, Eugenija, Mijo Lončarić, Dragica Malić, Slavko Pavešić, Mirko Peti, Vesna Zečević i Marija Znika. Hrvatska gramatika. Zagreb: Školska knjiga, 1997.

Belaj, Branimir i Goran Tanacković Faletar. Kognitivna gramatika hrvatskoga jezika. Knjiga prva. Imenska sintagma i sintaksa padeža. Zagreb: Disput, 2014.

Boryś, Wiesław. Słownik etymologiczny języka polskiego. Kraków: Wydawnictwo Literackie, 2005.

Doroszewski, Witold, red. Stownik Jezzyka Polskiego, PWN, <https://sp.pwn.pl/ doroszewski/>. Dostęp 14 kwietnia 2019.

Dubisz, Stanisław, red. Uniwersalny stownik języka polskiego. Warszawa: PWN, 2004. CD-ROM.

Dunaj, Bogusław, red. Wspótczesny stownik języka polskiego, Warszawa: Langenscheidt, 2009. CD ROM.

Feleszko, Kazimierz. Składnia genetiwu i wyrażeń przyimkowych z genetiwem w języku serbsko-chorwackim. Wrocław: Zakład Narodowy im. Ossolińskich, 1970.

Hrvatski jezični portal. Znanje. <http://hjp.znanje.hr>. Dostęp 13 kwietnia 2019.

Ivir, Vladimir. Teorija i tehnika prevođenja. Sremski Karlovci: Centar „Karlovačka gimnazija", 1978.

Kosek, Iwona. Przyczasownikowe frazy przyimkowo-nominalne $w$ zdaniach współczesnego języka polskiego. Olsztyn: Wydawnictwo Uniwersytetu Warmińsko-Mazurskiego, 1999.

Krążyńska, Zdzisława. Staropolskie konstrukcje z przyimkami. Część V. Poznań: Poznańskie Studia Polonistyczne, 2012.

Jojić, Ljiljana, red. Veliki rječnik hrvatskoga standardnog jezika, Zagreb: Školska knjiga, 2015. 
Lachur, Czesław. Polskie przyimki wtórne i jednostki o funkcji przyimkowej w użciu realnym. Materiaty do słownika (w zestawieniu z językiem rosyjskim). Tom 1. Kępa: Wydawnictwo Nowik sp. j., 2019.

Lesz-Duk, Maria. Czasowniki o składni przyimkowej w języku polskim. Częstochowa: Wydawnictwo Wyższej Szkoły Pedagogicznej w Częstochowie, 1988.

Lesz-Duk, Maria. Przyimki wtórne w języku polskim. Częstochowa: Wydawnictwo Akademii im. Jana Długosza, 2011.

Matas Ivanković, Ivana. Izražavanje prostora i vremena prijedlozima s genitivom u hrvatskom i ruskom jeziku. Zagreb: Institut za hrvatski jezik i jezikoslovlje, 2014.

Milewska, Beata. Stownik polskich przyimków wtórnych. Gdańsk: Wydawnictwo Uniwersytetu Gdańskiego, 2003.

Milewska, Beata. Przyimki wtórne we współczesnej polszczyźnie. Gdańsk: Wydawnictwo Uniwersytetu Gdańskiego, 2003.

Moguš, Milan, Maja Bratanić i Marko Tadić. Hrvatski čestotni rječnik. Zagreb: Školska knjiga, 1999.

Pranjković, Ivo. Druga hrvatska skladnja: Sintaktičke rasprave. Zagreb: Hrvatska sveučilišna naklada, 2001.

Przybylska, Renata. Polisemia przyimków polskich w świetle semantyki kognitywnej. Kraków: Universitas, 2002.

Silić, Josip i Ivo Pranjković. Gramatika hrvatskoga jezika za gimnazije $i$ visoka učilišta. Zagreb: Školska knjiga, 2005.

Skorupka, Stanisław. Słownik frazeologiczny języka polskiego. Tom 2. Warszawa: Wiedza Powszechna, 1985.

Šonje, Jure, red. Rječnik hrvatskoga jezika. Zagreb: Leksikografski zavod „Miroslav Krleža"; Školska knjiga, 2000.

Vince, Jasna. „Prostorni prijedložni izrazi u hrvatskom crkvenoslavenskom jeziku”. Slovo, vol. 60 (2010): 791-826.

Werwiński, Sławomir. „Czy przyimek ogólnorelacyjny $w$ stosunku do jest równoznaczny z jednostkami $w$ odniesieniu do i $w$ porównaniu $z$ ?" Linguistica Copernicana, vol. 4, no. 2 (2010): 157-173.

Żmigrodzki, Piotr, red. Wielki słownik języka polskiego, Instytut Języka Polskiego PAN, <https://wsjp.pl/index.php?pwh=0>. Dostęp 5 lipca 2020.

\section{Literatura źródłowa}

Desnica, Vladan. Proljeća Ivana Galeba. Zagreb: Večernji list, 2004.

Desnica, Vladan. Niespokojne wiosny. Tłum. Zygmunt Stoberski. Warszawa: Wydawnictwo Ministerstwa Obrony Narodowej, 1960.

Ferić, Zoran. „Blues za gospođu s crvenim mrljama“. W: Goli grad. Antologija hrvatske kratke priče 80-tih i 90-tih, red. Krešimir Bagić. 91-114. Zagreb: Naklada MD, 2003.

Ferić, Zoran. „Blues dla kobiety z czerwonymi plamami”. Tłum. Tomasz Illg. W: Nagie miasto. Antologia chorwackiego krótkiego opowiadania (short story) 
lat osiemdziesiątych $i$ dziewięćdziesiatych $X X$ wieku, red. Leszek Małczak. 144-139. Katowice: Wydawnictwo Uniwersytetu Śląskiego, 2009.

Ferić, Zoran. Mišolovka Walta Disneya. Zagreb: Naklada MD, 1996.

Ferić, Zoran. Pułapka na myszy Walta Disneya. Tłum. Gordana Đurđev i in. Sejny: Fundacja Pogranicze, 2007.

Furtinger, Zvonimir. „Trebam tvoje tijelo“. W: YU Sirius. Prva zbirka jugoslavenskog sf-a, red. Borivoj Jurković, 7-55. Zagreb: Vjesnik, 1978.

Furtinger, Zvonimir. Potrzebne mi twoje ciało. Tłum. Elżbieta Kwaśniewska. Warszawa: Iskry, 1986.

Horvat, Joža. Besa. Zagreb: Neretva, 2005.

Horvat, Joža. „Besa“ - dziennik podróży. Tłum. Jerzy Knabe. Gdańsk: Wydawnictwo Morskie, 1981.

Jergović, Miljenko. „Dijagnoza”. W: Goli grad. Antologija hrvatske kratke priče 80-tih i 90-tih, red. Krešimir Bagić, 118-119. Zagreb: Naklada MD, 2003.

Jergović, Miljenko. „Diagonoza”. Tłum. A. Białas. 2009. W: Nagie miasto. Antologia chorwackiego krótkiego opowiadania (short story) lat osiemdziesiatych $i$ dziewięćdziesiątych XX wieku, red. Leszek Małczak, 144-146. Katowice: Wydawnictwo Uniwersytetu Śląskiego, 2009.

Jergović, Miljenko. Freelander. Zagreb: Naklada Ljevak, 2008.

Jergović, Miljenko. Freelander. Tłum. Magdalena Petryńska. Sejny: Pogranicze, 2010.

Kušan, Ivan. Zagonetni dječak. Zagreb: Znanje, 1995.

Kušan, Ivan. Zagadkowy chłopiec. Tłum. Danuta Ćirlić-Straszyńska. Warszawa: Nasza Księgarnia, 1966.

Marinković, Ranko. Kiklop. Zagreb: Lukom, 1996.

Marinković, Ranko. Cyklop. Tłum. Krystyna Bąk. Łódź: Wydawnictwo Łódzkie, 1981.

Mićanović, Krešimir. „Enformel“. W: Goli grad. Antologija hrvatske kratke priče 80-tih i 90-tih, red. Krešimir Bagić, 85-89. Zagreb: Naklada MD, 2003.

Mićanović, Krešimir. „Informel“. Tłum. M. Kajzerek. W: Nagie miasto. Antologia chorwackiego krótkiego opowiadania (short story) lat osiemdziesiatych $i$ dziewięćdziesiątych XX wieku, red. Leszek Małczak, 107-111. Katowice: Wydawnictwo Uniwersytetu Śląskiego, 2009.

Mićanović, Krešimir. Trajekt. Zagreb: Meandar, 2004.

Mićanović, Krešimir. Prom. Grupa tłumaczy. Red. Leszek Małczak. Katowice: Wydawnictwo Uniwersytetu Śląskiego, 2011.

Novak, Slobodan. Mirisi, zlato i tamjan. Zagreb: Matica hrvatska, 1968.

Novak, Slobodan. Mirra, kadzidło i złoto. Tłum. Danuta Ćirlić-Straszyńska. Warszawa: Państwowy Instytut Wydawniczy, 1971.

Rudan, Vedrana. Ljubav na posljednji pogled. Zagreb: AGM, 2003.

Rudan, Vedrana. Miłość od ostatniego wejrzenia. Tłum. Marta Dobrowolska-Kierył. Warszawa: Drzewo Babel, 2005.

Slamnig, Ivan. Bolja polovica hrabrosti. Zagreb: Večernji List, 2004.

Slamnig, Ivan. Lepsza połowa odwagi. Tłum. Alija Dukanović. Warszawa: PIW, 1976. 


\section{Croatian protiv preposition and its Polish translation equivalents}

Summary: The Croatian protiv preposition is a rare preposition with a complementary genitive case government. Although lexicographical sources note the spatial and non-spatial meanings of this preposition, empirical studies only confirm the meanings from the abstract domain of adversativeness, i.e. expressing the opposite position, contradiction, disagreement with something, limiting, counteracting or protecting against something. The task that we set for ourselves in this work is to determine the resource of the Polish translation equivalents of the Croatian protiv preposition. The analysis will be carried out on a parallel corpus excerpted from contemporary Croatian literature written in 20th and 21st centuries and respective Polish translations. The work will use the method of translation equivalence, belonging to comparative linguistics methodology.

The study will consist of two parts. The first part will determine the meanings of the protiv preposition present in the built corpus and the right and left side environment of this preposition will be examined. The second part will be dedicated to equivalence. A resource of Polish equivalents will be presented and their lexical, grammatical and semantic features will be determined. Similarities and differences in the expression of similar content in both languages will be indicated and an attempt will be made to determine the translator's selection of factors for individual equivalents, e.g. in the form of limitations in the right and left side environment, shade of meaning or stylistic value. The statistical analysis will be an important element of the study, which in addition to the semantic characteristics will help determine the main Polish equivalent of the Croatian protiv preposition. The conducted study can be used in the lexicographic practice, didactics and translation.

Keywords: prepositions, cases, translation equivalence, Croatian language, Polish language 